\title{
NO AUSTRIANS IN SOUTH TYROL? WHY THE GERMAN-SPEAKING COMMUNITY IN ITALY'S SOUTH TYROL (ALTO ADIGE) PROVINCE IS NOT USUALLY CALLED AN AUSTRIAN MINORITY
}

\section{ABSTRACT}

The article discusses the question why the German-speakers in Northern Italy's South Tyrol province are only very rarely referred to as an Austrian minority, in spite of the fact that they were split off from Austria, and not Germany, in the aftermath of World War I. An analysis of the naming of German-speaking South Tyroleans in German, Austrian, Italian, and Englishspeaking news media, which demonstrates a preference for terms such as "German-speaking minority" or "German minority" over "Austrian minority" and equivalents, is followed by a discussion of three hypotheses to account for the situation. The author shows how the question of how to name the German-speaking South Tyroleans is closely intertwined with the issue of Austrian national identity and its re-orientation away from Germany in the aftermath of World War II. The author comes to the conclusion that the minority is not usually referred to as Austrian both due to the fact that it is difficult to include them in the young (civic) Austrian nation in a logically consistent manner, and due to the German-speaking South Tyroleans' own inconsistent self-identification as Austrians.

Key words: South Tyrol; Austrian nationalism; German minority; Austrian minority

MICHAEL JULIAN EMANUEL VOLKMER University of St Andrews, St. Andrews, United Kingdom E-mail: mjev@st-andrews.ac.uk This work was supported by the author's own resources.

No competing interests have been declared.

This is an Open Access article distributed under the terms of the Creative Commons Attribution 3.0 PL License (creativecommons.org/licenses/by/3.0/pl/), which permits redistribution, commercial and non-commercial, provided that the article is properly cited. (C) The Author(s) 2016.

Publisher: Institute of Slavic Studies, Polish Academy of Sciences [Wydawca: Instytut Slawistyki PAN] 


\section{NIE MA AUSTRIAKÓW W TYROLU POLUDNIOWYM? \\ DLACZEGO NIEMIECKOJĘZYCZNA WSPÓLNOTA WE WLOSKIEJ PROWINCJI TYROL POLUDNIOWY (ALTO ADIGE) ZWYKLE NIE JEST NAZYWANA MNIEJSZOŚCIĄ AUSTRIACKĄ}

\section{Streszczenie}

Artykuł podejmuje kwestię, dlaczego niemieckojęzyczna ludność północnowłoskiej prowincji Tyrol Południowy rzadko bywa nazywana mniejszością austriacką, pomimo tego że w efekcie I wojny światowej odłączona została ona od Austrii, a nie od Niemiec. Analiza nazewnictwa odnoszonego do niemieckojęzycznej ludności Tyrolu Południowego, które występuje w informacyjnych środkach przekazu: niemiecko-, austriacko-, włosko- i anglojęzycznych pozwala stwierdzić, że preferowane są określenia takie jak „mniejszość niemieckojęzyczna” lub „mniejszość niemiecka”, zamiast „mniejszość austriacka" i terminy ekwiwalentne. Następnie omówione zostały trzy hipotezy mogące wyjaśnić tę sytuację. Autor ukazuje, jak ściśle współzależą od siebie kwestia nazewnictwa niemieckojęzycznej ludności Tyrolu Południowego i kwestia austriackiej tożsamości narodowej oraz jej odchodzenia od Niemiec w następstwie II wojny światowej. Autor dochodzi do wniosku, że omawiana tu mniejszość zwykle nie jest uznawana za austriacką zarówno z tego powodu, że trudno jest umiejscowić ją w młodym (obywatelskim) narodzie austriackim w sposób logicznie konsekwentny, jak i z racji własnej niekonsekwentnej samoidentyfikacji niemieckojęzycznych Tyrolczyków Południowych jako Austriacy.

Słowa kluczowe: Tyrol Południowy; nacjonalizm austriacki; mniejszość niemiecka; mniejszość austriacka

Therefore I again and again spoke of the fact that the South Tyroleans are [above all] South Tyroleans, that the Tyroleans in their entirety, however, are Austrians, and that the South Tyroleans constitute therefore an Austrian minority in Italy, not a German. ${ }^{1}$

Bruno Kreisky

\section{INTRODUCTION}

n spite of Bruno Kreisky's insistence, the German-speaking inhabitants of Italy's South Tyrol province are very rarely referred to as an Austrian minority outside of Austria and

South Tyrol, and even in the latter two only very inconsistently. Much more frequently, they are referred to as either a German or a German-speaking minority. This is remarkable given the fact that South Tyrol was split off in 1919 from Austria, not from Germany, and had been part of Austria for many centuries, whereas it has never de jure been part of a state known as Germany. In this essay, I will attempt to account for why terms such as

1 Translations throughout the essay are my own. Original: "Deshalb sprach ich immer wieder bewusst davon, dass die Südtiroler Südtiroler, die Tiroler in ihrer Gesamtheit aber Österreicher sind und dass es sich bei den Südtirolern deshalb um eine österreichische Minderheit in Italien handle, nicht um eine deutsche." (Kreisky, 1988, p. 158) 
"German minority" or "German-speaking minority" are widely preferred over "Austrian minority" and equivalents. The topic of the essay is not South Tyrolean self-identification; this issue will only be addressed as far as it is necessary to account for the designations used by Non-South Tyroleans.

First of all, the prevalent ways of referring to the German-speaking South Tyroleans (hereafter called GSSTs) in the English-speaking world, Germany, Italy and Austria will be discussed. It will be demonstrated that, overall, designations referring to the GSSTs' language are the most common, followed by those containing the term "German" without a reference to language. It will be argued that the dearth of designations referring to Austria (with the exception of Austria itself, where the term "österreichische Minderheit" does have some currency) is due to three factors: First, the South Tyroleans have arguably only partially taken part in the process of Austrian Nationswerdung (Klenner, 1978) ("becoming a nation") that took place in the decades after World War II, and this lack of self-identification with the Austrian nation is reflected in how outsiders refer to the GSSTs. Second, the nature and history of Austrian nationalism makes it difficult to include the GSSTs in the Austrian nation in a logically consistent manner. Finally, as Austria, not Germany, is South Tyrol's internationally recognized Schutzmacht ${ }^{2}$ and the only country that might potentially endanger Italy's sovereignty over South Tyrol in the coming decades, terms such as "Austrian minority" could be perceived as not politically neutral or even irredentist and therefore avoided by some.

\section{NAMING THE GSSTS}

\section{The English-speaking world}

When referring to the GSSTs, the English-speaking world seems to overwhelmingly prefer foregoing any direct reference to ethnicity, instead opting for "neutral," language-based designations such as "German-speakers," "German-speaking minority" or "Germanspeaking citizens." This is confirmed by the Google search results shown in Table $1^{3}$, and by an analysis of international news media displayed in Table $2 .{ }^{4}$ The 1946 Treaty of Paris likewise refers to "German-speaking inhabitants," "the German-speaking element," "German-speaking citizens," and "German-speaking elements." ('Autonome Provinz Bozen - Südtirol', n.d.)

Another common English-language designation, although much less frequent than the above-described, is the one including "German," without explicit reference to language. This is demonstrated by Tables 1 and 2 and by the inclusion of the GSSTs in scholarly works such as Stefan Wolff's German Minorities in Europe: Ethnic Identity and Cultural Belonging. (Wolff, 2000) In many of these instances it is, however, unclear whether "Ger-

\section{-....}

2 Since the 1946 Gruber de Gasperi (or Paris) Agreement, Austria has functioned as South Tyrol's internationally recognized Schutzmacht ("protective power"). This effectively means that Austria has been accepted "as an international partner in the South Tyrol question" and thus can expect to be consulted on every major issue concerning the GSSTs and their autonomy. (Grote, 2012, pp. 81-83)

3 http://www.google.com [4 May 2015].

4 BBC (Bell, 2012a, 2012b; Willey, 1998, 2014); Al Jazeera (Scammell, 2013); The Guardian (Marchetti, 2014; Vulliamy, 1991). New York Times (Bohlen, 2014; 'Topics of the Times; Viva Alto Adige!', 1992); Washington Post (Noack, 2014; Wilson, 2011; The Telegraph (Alexander, 2011; Govan, 2011; Squires, 2010, 2011a, 2011b, 2012, 2014a, 2014b; Uhlig, 2001; 'Bolzano, Italy: A cultural guide', 2011). 
man" is employed as a mere shorthand for "German-speaking" or whether it is deliberately used as an ethnic designation. This is also true for the other analyses. In any case, the designation "Austrian" appears to be the least common in English (see Table 2).

Table 1: Google Search

\begin{tabular}{|l|c|c|c|}
\hline \multicolumn{1}{|c|}{ Search term } & $\begin{array}{c}\text { "Austrian minority } \\
\text { in Italy" }\end{array}$ & $\begin{array}{c}\text { "German minority } \\
\text { in Italy" }\end{array}$ & $\begin{array}{c}\text { "German-speaking } \\
\text { minority in Italy" }\end{array}$ \\
\hline Google Hits & 1,610 & 7,140 & 38,900 \\
\hline Google Scholar Hits & 8 & 26 & 27 \\
\hline
\end{tabular}

\section{Germany}

An analysis of 18 articles on South Tyrol from German print media yields the following results: The GSSTs are referred to 60 times as "Deutsche" or "deutsch," 44 times as "Deutschsprachige," "deutscher Sprache" or equivalent terms, and 34 times simply as "die Südtiroler," with the implied meaning of "non-Italian-speaking South Tyroleans." 5 Reference to an Austrian minority or ethnic Austrians is conspicuously absent from the articles (Table 2).

Italy

Like those in the English-speaking world and in Germany, the Italian media does not seem to be convinced of the existence of an Austrian minority in Italy. An analysis of 18 articles from the Italian newspapers Corriere della Sera and La Repubblica shows a clear preference (43 vs. 17) for terms such as "i tedeschi" and "la minoranza tedesca" over those referring directly to the language such as "gli altoatesini de lingua tedesca" and "del gruppo linguistico tedesco." ${ }^{6}$ None of the articles makes use of terms such as "Austrian minority" when referring to the GSSTs (Table 2). ${ }^{7}$

\section{Austria}

A 25-strong sample from Austrian media shows that "die Südtiroler"8 and equivalents are the most commonly used terms (28 instances), followed by "Deutschsprachige" and equivalents ( 23 instances). The Austrian sample is the only one that contains references

\section{-.....}

5 Der Spiegel (Albert, 2009; Aschbacher, 2012; Holm, 1999; Mayr, 2010a, 2010b; Wiegrefe, 2008; 'Die Deutschen haben doch wirklich alles', 1985; 'Ethnischer Käfig', 1981; 'Italien: Unruhe in den Alpen', 1991; 'König Laurins Rückkehr', 1955; 'Luis Durnwalder', 2008; 'Schlafende Riesen', 1985; 'Speck aus den Walschen', 1992; 'Teutonische Härte', 1979; 'Zersprengte Sprenger', 1966); Die Zeit (Bachmann, 2015; Schönau, 2011; Stehle, 1987).

6 It is likely that this strong preference for designations like "the Germans" or "German inhabitants" over those referring to the language, especially compared to the distributions in the other languages, can partly be attributed to the fact that there is no commonly-used shorthand term referring to speakers of a language equivalent to the English "German-speakers" or the German "Deutschsprachige" in the Italian language.

7 Corriere della Sera (Corrado, 1999; Galli Della Loggia, 2009; Gambarini, 2014; Gian Antonio, 1998, 2000; Gramigna, 2010; Imarisio, 2009; Vassalli, 2011; Vigna, 1998; Visentini, 1997, 1998, 2000a, 200b;'Una costellazione di piccoli partiti a destra della Svp', 1997); La Repubblica (Custodero, 2011; Meletti, 2008; Statera, 2007; Visetti, 2008; 'Cossiga: I'Alto Adige voti per scegliere tra Italia e Austria', 2006).

8 Here again, only such instances were counted where "die Südtiroler" clearly exclusively refers to the GSSTs. 
to an Austrian minority (ten instances); it also features a much weaker preference for "Deutsche" and equivalents (seven instances) than the sample from Germany. It must, however, be noted that use of the designation "österreichische Minderheit" and equivalents is limited to very few authors, and is completely absent from the 14 articles from Der Standard. ${ }^{9}$

Table 2: Comparison of the samples from English-language, German, Italian and Austrian media

\begin{tabular}{|l|c|c|c|c|}
\hline Designation & $\begin{array}{c}\text { "Germans," } \\
\text { "G. South } \\
\text { Tyroleans" and } \\
\text { equivalents }\end{array}$ & $\begin{array}{c}\text { "German-spea- } \\
\text { kers," "G.-spea- } \\
\text { king residents" } \\
\text { and equivalents }\end{array}$ & $\begin{array}{c}\text { "The South } \\
\text { Tyroleans" and } \\
\text { equivalents }\end{array}$ & $\begin{array}{c}\text { "Austrians," } \\
\text { "A. minority" } \\
\text { and equivalents }\end{array}$ \\
\hline $\begin{array}{l}\text { Frequency } \\
\text { (English-l. media; } \\
21 \text { articles) }\end{array}$ & $1(2.6 \%)$ & $37(97.4 \%)$ & - & - \\
\hline $\begin{array}{l}\text { Frequency } \\
\text { (German media; } \\
18 \text { articles) }\end{array}$ & $68(42.2 \%)$ & $58(36.0 \%)$ & $35(21.7 \%)$ & - \\
\hline $\begin{array}{l}\text { Frequency (Italian } \\
\text { media; } 18 \text { articles) }\end{array}$ & $43(71.7 \%)$ & $17(28.3 \%)$ & - & - \\
\hline $\begin{array}{l}\text { Frequency } \\
\text { (Austrian media; } \\
25 \text { articles) }\end{array}$ & $7(10.3 \%)$ & $23(33.8 \%)$ & $28(41.2 \%)$ & $10(14.7 \%)$ \\
\hline Total (78 articles) & $\mathbf{1 1 9 ( 3 6 . 4 \% )}$ & $\mathbf{1 3 5 ( 4 1 . 3 \% )}$ & $\mathbf{6 3 ( 1 9 . 3 \% )}$ & $\mathbf{1 0 ~ ( 3 . 1 \% )}$ \\
\hline
\end{tabular}

NO AUSTRIANS IN SOUTH TYROL?

The analysed data seems to confirm the assumption that, although the existence of an Austrian nation has come to be globally accepted, the GSSTs are not considered to be part of this nation. This implies that the wider world has accepted the Nationswerdung of the Austrians, but does not acknowledge that the GSSTs have taken part in it. There are arguably three possible explanations for this, which I will now proceed to examine. First, it is possible that the GSSTs have not-or only partially-participated in the process of Austrian Nationswerdung, and the wider world bases its terminology on that lack of Austrian self-identification on the part of the GSSTs. Or, to put it simply: We don't call them Austrians because they don't do it themselves.

Second, it is thinkable that the internationally prevalent terminology is based not on the GSSTs' self-identification, but on the fact that the international community simply does not think it "makes sense" that the GSSTs are Austrians. This would mean that the Austrian Nationswerdung has been accepted abroad, but, mainly due to its civic nature, only for Austria itself. Finally, it is a possibility that the GSSTs are not referred to as Austrians for political reasons, as acknowledging the existence of a coherent, strong

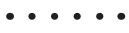

9 Der Standard (Mumelter, 2008, 2011a, 2011b, 2013a, 2013b, 2013c, 2014; Narodoslawsky, 2011; Niederndorfer, 2009; Prantner, 2008; Wallisch, 2013; 'Österreich bekräftigt Schutzmachtfunktion', 2012; 'Parteien empört über Verbot deutschsprachiger Ortsnamen', 2009; 'Südtiroler Schützen: Los von Rom “lieber heute als morgen"', 2011; 'Unterschriften-Aktion für Doppelstaatsbürgerschaft beginnt', 2010). Die Presse (Khol, 2008); Kleine Zeitung ('SVP regierte 65 Jahre mit absoluter Mehrheit', 2013); Kronen Zeitung ('Italien ist bald ein Nachbarland von Südtirol', 2013;'Thema: Südtirol', 2015); Salzburger Nachrichten (Hofer, 1998a, 1998b); Wiener Zeitung (Mathé, 2008; Reiter, 2009; Schausberger, 2014; Untersberger, 2009; 'Österreich hält die Hand über Minderheit', 2006). 
Austrian minority adjacent to Austrian territory might be seen as fuelling and legitimising separatist tendencies in South Tyrol.

\section{We don't call them Austrians because they don't do it themselves}

There is strong scholarly consensus that, up to the end of the Second World War, and even to some extent after that, the vast majority of German-speakers in what is today Austria (and, by extension, in what was Austria-Hungary before 1919) saw themselves as German. There had always been, of course, an Austrian, local, regional, and sometimes supranational identities competing with the German one, but at least in terms of ethnicity, hardly any German-speaking Austrian would have denied his or her belonging to the German Volk. (Cole, 2000, pp. 101-106, 334; Bruckmüller, 1998, pp. 370-372; John, 1999, pp. 29, 62)

Thus, the GSSTs still displayed a strong German self-identity when South Tyrol was awarded to Italy at St Germain, with which it would remain until today. ${ }^{10}$ During the interwar period, the first tentative voices within Austria began to argue for the Austrians' separateness from the German people, but this remained a minority view, and the only reason Austria did not join the emerging German republic in 1919 was the victorious powers' veto. (Knickerbocker, 2014, p. 72; Wodak, de Cillia, Reisigl, \& Liebhart, 2009, p. 51) In interwar Austria longing for unification with Germany was intense across the political spectrum, and there is no reason why identification with and longing for unification with Germany would have been any weaker in South Tyrol, especially in light of the suppression of everything German by the Italian Fascists. ${ }^{11}$ Of course there was nostalgia for the gone days of Habsburg rule, but the dismal political and economic state of the Austrian First Republic must have made identification with Austria as unattractive and unpopular as it was in the neighbouring former fatherland. (Knickerbocker, 2014, pp. 75, 90-92)

As a consequence, it is arguably only in in the aftermath of the events of 1938 that South Tyrol and Austria's identities started to strongly diverge. In Austria, the seven years of Nazi rule, including massive collaboration in Nazi crimes and all the privations suffered by the civilian population such as the Allied bombings, had a fundamental impact on the Austrian's self-perception, effectively causing a complete reorientation of their national identity. (Knickerbocker, 2014, p. 148) Whereas earlier, an ethnolinguistic model of nationalism-according to which the Austrians were self-evidently part of the German people and nation-had prevailed, the elites now espoused and spread through the educational system a new, civic form of nationalism that above all emphasised Austrian national distinctiveness from Germany. (Campbell, 2006, pp. 434, 470; Thaler, 1996, pp. 139-140). Although still not completely unquestioned in Austria itself, the Austrian's national reorientation has apparently been accepted by the wider world, including Germany, and thus Austrians are today only very rarely considered to be or referred to as Germans. (Thaler, 1996, pp. 198-199)

10 Except for the brief de facto incorporation into Nazi Germany 1943-45: After the overthrow of Mussolini and Italy's joining the Allied Powers, German troops occupied South Tyrol, which became part of the Operationszone Alpenvorland ("Operational Zone of the Alpine Foothills"). During the 20 months of occupation, South Tyrol was never formally annexed, but in many ways treated as if part of Nazi Germany. (Grote, 2012, p. 70).

11 The desire to be part of a Greater Germany was at least as widespread and strong among Austrian Social Democrats as among members of Conservative parties. This is demonstrated by the fact that many of their leaders, in spite of their fundamental opposition to National Socialism, and fully aware of the dangers they would face, publicly advocated Anschluss to Nazi Germany. (Thaler, 1996, p. 164). 
A strong point can be made that South Tyrol at least partially missed out on the Austrian process of Nationswerdung, because it neither shared Austria's incentives for it, nor the institutional tools to enforce it. Whereas the Austrians started vehemently emphasising their Austrianness and distinctiveness from Germandom mainly in order to be able to dissociate themselves from the Nazi crimes and portray themselves as "Hitler's first victim," the GSSTs' image had not been tarnished in the eyes of the world. (Art, 2006, pp. 105-109) On the contrary, in Western public discourse the GSSTs were frequently portrayed as the hapless victims of a Fascist dictatorship. ('Foreign Affairs', n.d.; Kreisky, 1988, p. 152)

Thus, one of the main functions of Austria's national reorientation - that of avoiding being associated with the crimes of the Nazis - had no raison d'être in South Tyrol, and the GSSTs felt no need for an Austrian-style rebranding. But even if there had been more of an incentive in South Tyrol to spread the new Austrian nationalism, the latter's civic nature and the fact that its top-down spread through the institutions was unfeasible in an educational system that continued to be dominated by Rome for another three decades would have rendered this a very difficult task. (Thaler, 1996, pp. 143-145, 150-153)

As a consequence of the above, the GSSTs today only display a very inconsistent self -identification with Austria, in spite of both the current and the former South Tyrolean Landeshauptmann (provincial president) frequently and pointedly calling the GSSTs an Austrian minority in public. ${ }^{12}$ Discussing the GSSTs' self-identification in detail would go beyond the scope of the essay, but the figures displayed in Table 3 seem to support this hypothesis. To sum up this point: Although they seem to have largely dropped their (ethnic) German identity, and have not acquired an Italian one, for that matter, there has not emerged a consensus among GSSTs of being somehow ethnically or nationally Austrian, and this lack of consensus within South Tyrol might be said to be reflected in the international verdict.

Table 3: Designations used by GSSTs quoted in news articles, and those used in the party program of the South Tyrolean People's Party (SVP) that has been South Tyrol's dominating party since 1948

\begin{tabular}{|l|c|c|c|c|}
\hline \multicolumn{1}{|c|}{ Designation } & $\begin{array}{c}\text { "Germans," } \\
\text { "G. South" } \\
\text { Tyroleans" } \\
\text { and equivalents }\end{array}$ & $\begin{array}{c}\text { "German-speakers," } \\
\text { "G.-speaking } \\
\text { residents" } \\
\text { and equivalents }\end{array}$ & $\begin{array}{c}\text { "The South } \\
\text { Tyroleans" and } \\
\text { equivalents }\end{array}$ & $\begin{array}{c}\text { "Austrians," } \\
\text { "A. minority" } \\
\text { and } \\
\text { equivalents }\end{array}$ \\
\hline $\begin{array}{l}\text { Frequency in the } \\
\text { SVP program" }\end{array}$ & 12 & 2 & 10 & 1 \\
\hline $\begin{array}{l}\text { Frequency in } \\
\text { GSSTs' } \\
\text { statements quoted } \\
\text { in articles analysed }\end{array}$ & 11 & 2 & 6 & 7 \\
\hline
\end{tabular}

12 Luis Durnwalder (in office 1989-2014) and Arno Kompatscher (since 2014). (Niederndorfer, 2009; 'Kompatscher: „Österreich ist mein Vaterland”', 2014).

13 'Das neue Programm der Südtiroler Volkspartei' (1993)

14 Al Jazeera (Scammell, 2013); The Guardian (Marchetti, 2014); Der Spiegel (Mayr, 2010b; Holm, 1999; 'Die Deutschen haben doch wirklich alles', 1985; 'Ethnischer Käfig', 1981); Corriere della Sera (Imarisio, 2009; Gian Antonio, 1998); La Repubblica (Visetti, 2008); Der Standard (Niederndorfer, 2009; 'Südtiroler Schützen: Los von Rom "lieber heute als morgen"', 2011); unsertirol ('Kompatscher: „Österreich ist mein Vaterland"', 2014). 
We don't call them Austrians because there is no such thing as a "Volksösterreicher"

As described above, it also seems possible that the GSSTs are not usually referred to as Austrians because the nature of the young Austrian nationalism makes the very concept of historic communities of "ethnic Austrians" living abroad seem implausible. As mentioned above, Austrian nationalism was conceived as a civic antithesis to German ethnic nationalism, and as such at least in theory has claimed only those people as Austrian who possessed an Austrian passport.

As a consequence of the civic orientation of Austrian nationalism, and in spite of occasional attempts to retroactively cast the German-speakers of the Habsburg monarchy as proto-(ethnic) Austrians and to introduce the concept of "Volksösterreicher" 15 to describe the remnants of these groups in other countries, the notion of historically grown ethnically Austrian communities abroad has never really caught on, not even in Austria. (Campbell, 2006, p. 437) So one is tempted to ask: If the Austrians in the Bohemian lands became known exclusively as Sudeten Germans, those in Galicia as Galician Germans and those in Bucovina as Bucovina Germans, and hence all somehow lost their Austrian "labels" once they found themselves outside the state of Austria, why should those in South Tyrol have somehow kept theirs or retroactively acquired a nationalised version of it, given that they, like these other groups, were split off from Austria before the Nationswerdung? (Campbell, 2006, pp. 437-439)

The task of coherently including the GSSTs in the nascent Austrian nation was-and that of coherently including them in today's Austrian nation therefore still is-further complicated by the fact that they had missed out on a crucial part of the nationalist narrative. Although they certainly shared many of the Austrians' newly emphasised, allegedly common traditions and historical experiences like Heimat ${ }^{16}$ consciousness, Catholicism and centuries-long Habsburg rule, they lacked the supposedly crucial, defining experience of and resistance to the Nazi "occupation," which according to many post-war Austrian historians had been the decisive event in making the Austrians realise how little they had in common with the despicable Germans and moulded them into a nation. (Utgaard, 1997, pp. 202, 213, 1999, pp. 128-129)

\section{We don't call them Austrians out of respect for the territorial status quo}

Finally, it would also be thinkable that people refrain from calling the GSSTs Austrians out of respect for the territorial status quo in Europe. Austria is, after all, the only country that is regularly implicated in South Tyrolean claims to secede from Italy, and the only country that has some kind of historical claim to the territory. Thus, calling the GSSTs Austrians might be seen as implicitly acknowledging that South Tyrolean separatists have a legitimate claim, whereas calling them Germans or German-speakers is not burdened with a comparable evocative undertone.

15 "Ethnic Austrians" living beyond Austria's borders, analogous to the pre-WWII concept of "Volksdeutsche."

16 Heimat is a German concept without a direct English equivalent, describing the place or region where a person was born and raised, and the landscape, traditions, emotions, language, etc. associated with it. The closest English translation would be "home" or "homeland." 
In this essay, I have first analysed the prevalent ways of referring to the GSSTs in several countries, which yielded the result that internationally, the term "Austrian minority" and equivalents are very uncommon. I then suggested and examined three hypotheses to account for this.

Although the "political correctness" hypothesis might be of some relevance with respect to the wording of post-WWII official documents like the 1946 Paris Agreement or the terminology used in Italian newspapers, it is unlikely that political sensitivity plays a big role in the terminology used in the English-speaking world today, especially in academia. Therefore, this hypothesis should be considered the least relevant one. The remaining two hypotheses, i.e. that the GSSTs are not usually called Austrians either because they themselves only very inconsistently do it or because it does not seem logically consistent to do so, both seem plausible. The former hypothesis might be said to be slightly more valid, however, as its line of reasoning requires no prior knowledge, whereas that of the latter is arguably only open to people with sufficient historical understanding. There is unquestionably ample room for further research left, especially on the reasons for terminological differences between countries and languages. It is, for example, far from clear whether those international observers who use designations such as "German" for the South Tyroleans mean to convey a reference to ethnicity, or whether they simply use it as a stylistic alternative or convenient shorthand term for "German speakers."

\section{BIBLIOGRAPHY}

Internet Sources

English-Language Sources

\section{Al Jazeera}

Scammell, R. (2013, February 23). German-speaking Italians reassess Rome ties. Al Jazeera. Retrieved 26 February 2015, from http://www.aljazeera.com/indepth/features/ 2013/02/20132197189990704.html?utm=from-old-mobile

\section{BBC}

Bell, B. (2012a, October 3). Should South Tyrol subsidise Italy's struggling economy? [Including video]. BBC. Retrieved 2 March 2015, from http://www.bbc.co.uk/news/worldeurope-19810901

Bell, B. (2012b, December 8). South Tyrol's identity crisis: Italian, German, Austrian...? BBC. Retrieved 2 March 2015, from http://www.bbc.co.uk/news/magazine-20633126

Willey, D. (1998, February 3). Despatches. BBC. Retrieved 2 March 2015, from http:// news.bbc.co.uk/1/hi/despatches/53200.stm

Willey, D. (2014, September 19). How Scotland's 'No' vote resonates around the world Italy. BBC. Retrieved 2 March 2015, from http://www.bbc.co.uk/news/world-29272728

\section{New York Times}

Bohlen, C. (2014, March 24). Italy's historic multicultural compromise. New York Times. Retrieved 3 March 2015, from http://www.nytimes.com/2014/03/25/world/europe/italys-historic-multicultural-compromise.html?_r=0 
Topics of the Times; Viva Alto Adige! (1992, June 14). New York Times. Retrieved 3 March 2015, from http://www.nytimes.com/1992/06/14/opinion/topics-of-the-timesviva-alto-adige.html

\section{The Guardian}

Marchetti, S. (2014, May 30). The South Tyrol identity crisis: to live in Italy, but feel Austrian. The Guardian. Retrieved 2 March 2015, from http://www.theguardian.com/education/2014/may/30/south-tyrol-live-in-italy-feel-austrian

Vulliamy, E. (1991, November 22). Italy demolishes Cavour's jigsaw. The Guardian. Retrieved 2 March 2015, from http://www.theguardian.com/world/1991/nov/22/italy.edvulliamy

\section{The Telegraph}

Alexander, H. (2011, October 30). North Italy's success story amid faltering faith in Rome. The Telegraph. Retrieved 3 March 2015, from http://www.telegraph.co.uk/finance/financialcrisis/8857262/North-Italys-success-story-amid-faltering-faith-in-Rome.html

Bolzano, Italy: A cultural guide. (2011, October 17). The Telegraph. Retrieved 3 March 2015, from http://www.telegraph.co.uk/travel/destinations/europe/italy/8830981/Bolzano-ltaly-A-cultural-guide.html

Govan, F. (2011, July 11). National Day celebrations in other parts of Europe. The Telegraph. Retrieved 3 March 2015, from http://www.telegraph.co.uk/news/worldnews/ europe/spain/8630280/National-Day-celebrations-in-other-parts-of-Europe.html

Squires, N. (2010, April 12). Nine dead as Italian train derailed in mudslide. The Telegraph. Retrieved 3 March 2015, from http://www.telegraph.co.uk/news/worldnews/europe/ italy/7581843/Nine-dead-as-Italian-train-derailed-in-mudslide.html

Squires, N. (2011a, February 15). Italy anniversary celebrations highlight divide after 150 years. The Telegraph. Retrieved 3 March 2015, from http://www.telegraph.co.uk/ news/worldnews/europe/italy/8325271/Italy-anniversary-celebrations-highlight-divideafter-150-years.html

Squires, N. (2011b, April 26). Language wars in South Tyrol. The Telegraph. Retrieved 3 March 2015, from http://www.telegraph.co.uk/news/worldnews/europe/italy/8473351/Language-wars-in-South-Tyrol.html

Squires, N. (2012, May 20). Four dead after powerful earthquake strikes Italy. The Telegraph. Retrieved 3 March 2015, from http://www.telegraph.co.uk/news/worldnews/ europe/italy/9277684/Four-dead-after-powerful-earthquake-strikes-Italy.html

Squires, N. (2014a, April 27). Farmers in Italy's South Tyrol region want an end to bear hunting ban. The Telegraph. Retrieved 3 March 2015, from http://www.telegraph. co.uk/news/worldnews/europe/italy/10790022/Farmers-in-Italys-South-Tyrol-regionwant-an-end-to-bear-hunting-ban.html

Squires, N. (2014b, May 13). Rapid rise of forests changes the landscape for Italians. The Telegraph. Retrieved 3 March 2015, from http://www.telegraph.co.uk/news/worldnews/ europe/italy/10828717/Rapid-rise-of-forests-changes-the-landscape-for-Italians.html

Uhlig, R. (2001, January 1). Why climbers don't care who is first among equals. The Telegraph. Retrieved 3 March 2015, from http://www.telegraph.co.uk/news/1399776/Why -climbers-dont-care-who-is-first-among-equals.html

\section{Washington Post}

Noack, R. (2014, September 18). These 8 places in Europe could be the next to try for independence. Washington Post. Retrieved 3 March 2015, from http://www.washing- 
tonpost.com/blogs/worldviews/wp/2014/09/18/if-scotland-breaks-away-these-8-placesin-europe-could-be-next/

Wilson, J. (2011, December 27). Wine: In Alto Adige, bottles to make you forget pinot grigio. Washington Post. Retrieved 3 March 2015, from http://www.washingtonpost.com/lifestyle/food/wine-in-aldo-adige-bottles-to-make-you-forget-pinot-grigio/2011/12/21/glQAEDHhKP_story.html

Sources from Germany (in German)

\section{Der Spiegel}

Albert, S. (2009, January 31). Ein Hauch von Süden. Der Spiegel. Retrieved 24 February 2015, from http://www.spiegel.de/reise/europa/bozen-ein-hauch-von-sueden-a-601705. html

Aschbacher, A. (2012, March 5). Los von Rom. Der Spiegel. Retrieved 24 February 2015, from http://www.spiegel.de/spiegel/print/d-84251229.html

Die Deutschen haben doch wirklich alles. (1985, October 31). Der Spiegel. Retrieved 24 February 2015, from http://www.spiegel.de/spiegel/print/d-13532081.html

Ethnischer Käfig. (1981, October 5). Der Spiegel. Retrieved 2 March 2015, from http:// www.spiegel.de/spiegel/print/d-14335766.html

Holm, C. (1999, November 15). Properer Populist. Der Spiegel. Retrieved 24 February 2015, from http://www.spiegel.de/spiegel/print/d-15083572.html

Italien: Unruhe in den Alpen. (1991, September 9). Der Spiegel. Retrieved 24 February 2015, from http://www.spiegel.de/spiegel/print/d-13491434.html

König Laurins Rückkehr. (1955, October 5). Der Spiegel. Retrieved 20 February 2015, from http://www.spiegel.de/spiegel/print/d-31971318.html

Luis Durnwalder. (2008, January 14). Der Spiegel. Retrieved 24 February 2015, from http://www.spiegel.de/spiegel/print/d-55411044.html

Mayr, W. (2010a, August 23). Der ewige Durni. Der Spiegel. Retrieved 24 February 2015, from http://www.spiegel.de/spiegel/print/d-73388980.html

Mayr, W. (2010b, October 16). Krankhaftes Nicken. Der Spiegel. Retrieved 24 February 2015, from http://www.spiegel.de/spiegel/print/d-17596480.html

Schlafende Riesen. (1985, December 9). Der Spiegel. Retrieved 20 February 2015, from http://www.spiegel.de/spiegel/print/d-13515660.html

Speck aus den Walschen. (1992, November 9). Der Spiegel. Retrieved 24 February 2015, from http://www.spiegel.de/spiegel/print/d-13691170.html

Teutonische Härte. (1979, September 24). Der Spiegel. Retrieved 2 March 2015, from http://www.spiegel.de/spiegel/print/d-39868924.html

Wiegrefe, K. (2008, March 22). Bozener Bumser. Der Spiegel. Retrieved 24 February 2015, from http://www.spiegel.de/spiegel/print/d-56299094.html

Zersprengte Sprenger. (1966, May 2). Der Spiegel. Retrieved 2 March 2015, from http:// www.spiegel.de/spiegel/print/d-46407120.html

\section{Die Zeit}

Bachmann, B. (2015, March 26). Daheim bei Fremden. Die Zeit. Retrieved 6 May 2015, from http://www.zeit.de/2015/13/italiener-minderheit-deutschsprachiges-suedtirol

Schönau, B. (2011, February 28). Was hält Italien noch zusammen? Die Zeit. Retrieved 6 May 2015, from http://www.zeit.de/2011/09//talien-Jahrestag-Einigung

Stehle, H. (1987, August 14). Südtirol: Ewige Helden. Die Zeit. Retrieved 6 May 2015, from http://www.zeit.de/1987/34/suedtirol-ewige-helden 
Sources from Italy (in Italian)

\section{Corriere della Sera}

Corrado, S. (1999, July 20). Alto Adige, un modelo di convivenza possibile. Corriere de/la Sera. Retrieved 3 March 2015, from http://archiviostorico.corriere.it/1999/luglio/20/ Alto_Adige_modello_convivenza_possibile_co_0_9907204748.shtml

Galli Della Loggia, E. (2009, May 8). I separati dell'Alto Adige. Corriere della Sera. Retrieved 2 March 2015, from http://www.corriere.it/editoriali/09_maggio_08/editoriale_alto_ adige_ernesto_galli_della_loggia_fb5d76a4-3b8e-11de-a872-00144f02aabc.shtml

Gambarini, F. (2014, September 17). Mappa degli indipendentisti europei. Corriere della Sera. Retrieved 2 March 2015, from http://www.corriere.it/esteri/14_settembre_11/oltre-scozia-patchwork-indipendentisti-europei-d1 c8e8ac-39bf-11e4-99d9-a50cd0173d5f. shtml

Gian Antonio, S. (1998, May 4). II Brennero per me resta una ferita. Corriere della Sera. Retrieved 3 March 2015, from http://archiviostorico.corriere.it/1998/maggio/04/Brennero_per_resta_una_ferita_co_0_9805047051.shtml

Gian Antonio, S. (2000, February 2). Magnago: “E'solo un demagogo, questo assedio lo rafforza". Corriere della Sera. Retrieved 3 March 2015, from http://archiviostorico.corriere.it/2000/febbraio/02/Magnago_solo_demagogo_questo_assedio_co_0_ 0002021550.shtml

Gramigna, A. (2010, July 23). II governo a Bolzano: via i cartelli in tedesco o lo facciamo noi. Corriere della Sera. Retrieved 2 March 2015, from http://www.corriere.it/cronache/10_luglio_23/I-governo-a-Bolzano_3b8ff9c0-9621-11df-852a-00144f02aabe.shtml

Imarisio, M. (2009, May 7). Bolzano, riparte la campagna anti-italiani. Corriere della Sera. Retrieved 2 March 2015, from http://www.corriere.it/politica/09_maggio_07/bolzano_campagna_anti_italiana_svp_solo_candidati_tedeschi_741d8fe2-3ac8-11de-b51200144f02aabc.shtml

Una costellazione di piccoli partiti a destra della Svp. (1997, February 20). Corriere della Sera. Retrieved 3 March 2015, from http://archiviostorico.corriere.it/1997/febbraio/20/ Una_costellazione_piccoli_partiti_destra_co_0_9702206112.shtml

Vassalli, S. (2011, February 28). Bolzano, monumento alla vittoria? Macché, alla discordia. Corriere della Sera. Retrieved 2 March 2015, from http://www.corriere.it/cultura/11_febbraio_28/vassalli-bolzano-monumento-vittoria_0e86517e-432b-11e0-bd8e86c2288d7465.shtml

Vigna, E. (1998, July 28). Pristina non e'Bolzano, il modello altoatesino servirebbe solo a una pulizia etnica burocratica. Corriere della Sera. Retrieved 3 March 2015, from http://archiviostorico.corriere.it/1998/luglio/28/Pristina_non_Bolzano_modello_altoatesino_co_0_9807281532.shtml

Visentini, T. (1997, March 21). Per Scalfaro in Alto Adige sindaci senza fascia tricolore. Corriere della Sera. Retrieved 3 March 2015, from http://archiviostorico.corriere. it/1997/marzo/21/Per_Scalfaro_Alto_Adige_sindaci_co_0_97032113207.shtml

Visentini, T. (1998, December 3). Bressanone, apre pub Clientela di clase: non vogliamo italiani. Corriere della Sera. Retrieved 3 March 2015, from http://archiviostorico.corriere.it/1998/dicembre/03/Bressanone_apre_pub_Clientela_classe_co_0_98120311099. shtml

Visentini, T. (2000a, May 30). Bolzano, vince la centrosinistra. Corriere della Sera. Retrieved 3 March 2015, from http://archiviostorico.corriere.it/2000/maggio/30/Bolzano_vince_centrosinistra_co_0_0005304551.shtml 
Visentini, T. (2000b, August 12). Svp, attaco al centrodesta. Corriere della Sera. Retrieved 3 March 2015, from http://archiviostorico.corriere.it/2000/agosto/12/Svp_attacco_centrodestra_co_0_0008128650.shtml

\section{La Repubblica}

Cossiga: I'Alto Adige voti per scegliere tra Italia e Austria. (2006, May 25). La Repubblica. Retrieved 3 March 2015, from http://ricerca.repubblica.it/repubblica/archivio/repubblica/2006/05/25/cossiga-alto-adige-voti-per-scegliere.html?ref=search

Custodero, A. (2011, February 12). Unità d'Italia, la festa nel caos Lega e Alto Adige sfidano il Colle. La Repubblica. Retrieved 3 March 2015, from http://ricerca.repubblica.it/repubblica/archivio/repubblica/2011/02/12/unita-italia-la-festa-nel-caos-lega.html?ref=search

Meletti, J. (2008, June 3). La battaglia del Tedesco negli asili di Bolzano. La Repubblica. Retrieved 3 March 2015, from http://ricerca.repubblica.it/repubblica/archivio/repubblica/2008/06/03/la-battaglia-del-tedesco-negli-asili-di.html?ref=search

Statera, A. (2007, March 23). II compromesso étnico che copre d'oro Bolzano. La Repubblica. Retrieved 3 March 2015, from http://ricerca.repubblica.it/repubblica/archivio/ repubblica/2007/03/23/il-compromesso-etnico-che-copre-oro.html?ref=search

Visetti, G. (2008, September 2). Sudtirolo la tentazione austriaca. La Repubblica. Retrieved 3 March 2015, from http://ricerca.repubblica.it/repubblica/archivio/repubblica/2008/09/02/sudtirolo-la-tentazione-austriaca.html?ref=search

Sources from Austria (in German)

\section{Der Standard}

Mumelter, G. (2008, October 23). Die Angst vor dem CSU-Syndrom. Der Standard. Retrieved 3 March 2015, from http://derstandard.at/1224776218029/Die-Angst-vor-demCSU-Syndrom

Mumelter, G. (2011a, February 8). Durnwalder: "Österreichische Minderheit". Der Standard. Retrieved 26 February 2015, from http://derstandard.at/1296696681529/150-Jahre-Italien-Suedtirol-will-nicht-mitfeiern

Mumelter, G. (2011b, June 3). Bomben für die Selbstbestimmung. Der Standard. Retrieved 3 March 2015, from http://derstandard.at/1304553612154/Bomben-fuer-dieSelbstbestimmung

Mumelter, G. (2013a, January 3). Südtirol: Alte Schlachtrufe statt Zukunftskonzepte. Der Standard. Retrieved 3 March 2015, from http://derstandard.at/1356426696876/Suedtirol-Alte-Schlachtrufe-statt-Zukunftskonzepte

Mumelter, G. (2013b, October 24). Südtirol: Wahl besiegelt Ende der Ära Durnwalder. Der Standard. Retrieved 3 March 2015, from http://derstandard.at/1381369635291/ Suedtirol-Wahl-besiegelt-Ende-der-Aera-Durnwalder

Mumelter, G. (2013c, October 28). Ergebnis der Südtirol-Wahl: Parallele Gesellschaften. Der Standard. Retrieved 3 March 2015, from http://derstandard.at/1381370178380/ Ergebnis-der-Suedtirol-Wahl-Parallele-Gesellschaften

Mumelter, G. (2014, November 17). Südtirol: Eva Klotz steigt aus Landtag aus. Der Standard. Retrieved 3 March 2015, from http://derstandard.at/2000008261930/SuedtirolEva-Klotz-steigt-aus-Landtag-aus

Narodoslawsky, B. (2011, June 27). “Es geht gar nicht um einen Anschluss". Der Standard. Retrieved 3 March 2015, from http://derstandard.at/1308679420730/FPOe-Suedtirolsprecher-Es-geht-gar-nicht-um-einen-Anschluss 
Niederndorfer, F. (2009, July 27)."Italien hat keine Angst, dass Österreich ihm den Krieg erklärt". Der Standard. Retrieved 3 March 2015, from http://derstandard.at/ 1246543101176/derStandardat-Interview-Italien-hat-keine-Angst-dass-Oesterreich-ihm -den-Krieg-erklaert

Österreich bekräftigt Schutzmachtfunktion. (2012, November 9). Der Standard. Retrieved 3 March 2015, from http://derstandard.at/1350260942899/Suedtirol-Oesterreich-bekraeftigt-Schutzmachtfunktion

Parteien empört über Verbot deutschsprachiger Ortsnamen. (2009, December 16). Der Standard. Retrieved 3 March 2015, from http://derstandard.at/1259282092272/Parteien-empoert-ueber-Verbot-deutschsprachiger-Ortsnamen

Prantner, C. (2008, October 27). Wahlen in Südtirol: Verwelkendes Edelweiß. Der Standard. Retrieved 3 March 2015, from http://derstandard.at/1224776489916/Wahlen-inSuedtirol-Verwelkendes-Edelweiss

Südtiroler Schützen: Los von Rom "lieber heute als morgen". (2011, February 12). Der Standard. Retrieved 3 March 2015, from http://derstandard.at/1297216147148/150Jahre-Italien-Suedtiroler-Schuetzen-Los-von-Rom-lieber-heute-als-morgen

Unterschriften-Aktion für Doppelstaatsbürgerschaft beginnt. (2010, August 26). Der Standard. Retrieved 3 March 2015, from http://derstandard.at/1282273648629/Unterschriften-Aktion-fuer-Doppelstaatsbuergerschaft-beginnt

Wallisch, G. (2013, May 17). "Man wird wie an einem Gummiband zurückgezogen". Der Standard. Retrieved 3 March 2015, from http://derstandard.at/1363711427858/Manwird-wie-an-einem-Gummiband-zurueckgezogen

\section{Die Presse}

Khol, A. (2008, November 3). Südtirol am Scheideweg. Die Presse. Retrieved 4 March 2015, from http://diepresse.com/home/meinung/quergeschrieben/andreaskhol/427243/ Sudtirol-am-Scheideweg?from=suche. intern. portal

\section{Kleine Zeitung}

SVP regierte 65 Jahre mit absoluter Mehrheit. (2013, October 28). Kleine Zeitung. Retrieved 4 March 2015, from http://www.kleinezeitung.at/k/politik/4097527/Sudtirol_SVPregierte-65-Jahre-mit-absoluter-Mehrheit?from=suche.intern. portal

\section{Kronen Zeitung}

Italien ist bald ein Nachbarland von Südtirol. (2013, May 15). Kronen Zeitung. Retrieved 4 March 2015, from http://www.krone.at/Welt/Italien_ist_bald_ein_Nachbarland_von_ Suedtirol-Schuetzen-Obmann_-Story-361473

Thema: Südtirol. (2015, April 5). Kronen Zeitung. Retrieved 4 March 2015, from http:// www.krone.at/Themen/Suedtirol-Thema-8711

\section{Salzburger Nachrichten}

Hofer, E. (1998a, March 13). Südtirol im Wandel. Salzburger Nachrichten. Retrieved 4 March 2015, from http://search.salzburg.com/display/SNA21441-19980314

Hofer, E. (1998b, June 21). Südtirols starker Landeshauptmann. Salzburger Nachrichten. Retrieved 4 March 2015, from http://search.salzburg.com/display/SNA22544-19980622

\section{Wiener Zeitung}

Mathé, A. U. (2008, October 24). SVP-Verlust brächte schlechtere Karten in Rom. Wiener Zeitung. Retrieved 15 April 2015, from http://www.wienerzeitung.at/meinungen/analysen/252829_SVP-Verlust-braechte-schlechtere-Karten-in-Rom.html 
Schausberger, F. (2014, March 13). Südtirol als Modell für die Krim. Wiener Zeitung. Retrieved 4 March 2015, from http://www.wienerzeitung.at/meinungen/gastkommentare/614987_Suedtirol-als-Modell-fuer-die-Krim.html

Reiter, E. (2009, August 3). Die Südtiroler wollen keine Zurufe aus Wien. Wiener Zeitung. Retrieved 15 April 2015, from ttp://www.wienerzeitung.at/meinungen/gastkommentare/233806_Die-Suedtiroler-wollen-keine-Zurufe-aus-Wien.html

Untersberger, A. (2009, July 28). Südtirol: Die Fakten. Wiener Zeitung. Retrieved 15 April 2015, from http://www.wienerzeitung.at/meinungen/kommentare/234110_SuedtirolDie-Fakten.html

Österreich hält die Hand über Minderheit [including table]. (2006, April 26). Wiener Zeitung. Retrieved 4 March 2015, from http://www.wienerzeitung.at/nachrichten/oesterreich/politik/117404_Oesterreich-haelt-die-hand-ueber-minderheit.html

\section{unsertirol.com}

Kompatscher: "Österreich ist mein Vaterland”. (2014, October 8). Unsertirol.com. Retrieved 26 February 2015, from http://www.unsertirol24.com/2014/10/08/kompatscheroesterreich-ist-mein-vaterland/

Other Sources

\section{Web Presence of the Province of Bolzano-South Tyrol}

Autonome Provinz Bozen - Südtirol. (n.d.). Retrieved 2 March 2015, from http://www.provincia.bz.it/news/de/publikationen.asp?publ_action=4\&publ_article_id=1588

\section{Web Presence of the South Tyrolean People's Party (SVP)}

Das neue Programm der Südtiroler Volkspartei. (1993). Retrieved 5 May 2015, from http://www.svp.eu/smartedit/documents/download/grundsatzprogramm.pdf

\section{Google}

Google. (n.d.). Retrieved 4 May 2014, from http://www.google.com

\section{http://hansard.millbanksystems.com (Official Reports of debates in the Commons and Lords)}

Foreign Affairs. (n.d.). Retrieved 14 April 2015, from http://hansard.millbanksystems.com/ commons/1946/jun/04/foreign-affairs

\section{Printed Sources}

Art, D. (2006). The politics of the Nazi past in Germany and Austria. Cambridge: Cambridge University Press.

Bruckmüller, E. (1998). Die Entwicklung des Österreichbewusstseins. In R. Kriechbaumer (Ed.), Österreichische Nationalgeschichte nach 1945: Die Spiegel der Erinnerung: Die Sicht von innen (Vol. 1, pp. 369-396). Wien: Böhlau.

Campbell, D. (2006). The shadow of the Habsburgs: Memory and national identity in Austrian politics and education, 1918-1955 (PhD Dissertation). University of Maryland.

Cole, L. (2000). "Für Gott, Kaiser und Vaterland" - Nationale Identität der deutschsprachigen Bevölkerung Tirols 1860-1914. (C. Tacke, Trans.). Frankfurt/Main: Campus Verlag.

Grote, G. (2012). The South Tyrol question, 1866-2010: From national rage to regional state. Oxford; New York: Peter Lang. 
John, M. (1999). We do not even possess ourselves. Austrian History Yearbook, 30, 17-64. http://dx.doi.org/10.1017/S0067237800015952

Klenner, F. (1978). Eine Renaissance Mitteleuropas: Die Nationswerdung Österreichs. Vienna: Europaverlag.

Knickerbocker, J. (2014). Österreich und Anschluss - ponderous dilemma of Austrian identity (1848-1948) (PhD Dissertation). University at Albany, State University of New York.

Kreisky, B. (1988). Im Strom der Politik - Erfahrungen eines Europäers. Berlin: Siedler Verlag.

Thaler, P. (1996). Constructing national identity in an advanced society: The Austrian experience (PhD Dissertation). University of Minnesota.

Thorpe, J. (2011). Austrians. In G. E. Cole (Ed.), Ethnic groups of Europe: An encyclopedia (pp. 23-28). Santa Barbara, California: ABC-CLIO.

Utgaard, P. (1997). Forgetting the Nazis: Schools, identity, and the "Austria-as-victim" myth since 1945 (PhD dissertation). Washington State University.

Utgaard, P. (1999). From "Blümchenkaffee" to "Wiener Melange": Schools, identity, and the birth of the "Austria-as-victim" myth, 1945-55. Austrian History Yearbook, 30, 127-158. http://dx.doi.org/10.1017/S0067237800015988

Wodak, R., de Cillia, R., Reisigl, M., \& Liebhart, K. (2009). The discursive construction of national identity (2nd ed.). (A. Hirsch et al., Trans.). Edinburgh: Edinburgh University Press.

Wolff, S. (Ed.). (2000). German minorities in Europe: Ethnic identity and cultural belonging. New York: Berghahn.

\section{APPENDIX}

The online newspaper articles throughout were chosen by searching the online archives of the respective newspaper for the terms "South Tyrol" and "Alto Adige" in the case of the English-language media, "Südtirol" in the case of Der Spiegel and the Austrian newspapers, and Alto-Adige in the case of the Italian newspapers, and then selecting only those containing relevant references to the GSSTs. References that clearly have no ethnic but a mere linguistic dimension, such as "German schools" or "German last names," were not included, neither were those referring to GSSTs in the pre-WWII era, as it is commonly accepted that the minority was considered to be and self-identified as ethnically German then.

\footnotetext{
Non-English Terms used in the Article:

"deutsch": German (adjective)

"Deutscher": German (singular noun)

"Deutsche": Germans (plural noun)

"Deutschsprachiger": German-speaker (singular noun)

"Deutschsprachige": German-speakers (plural noun)

"deutschsprachig", "deutscher Sprache": German-speaking

"die Südtiroler": The South Tyroleans (plural noun)

"Österreicher": Austrian (singular noun)

"(die) Österreicher": (the) Austrians (plural noun)
} 
"österreichische Minderheit": Austrian minority

"i tedeschi": the Germans (plural noun)

"la minoranza tedesca": the German minority

"gli altoatesini de lingua tedesca": the German-speaking South Tyroleans

"del gruppo linguistico tedesco": belonging to the German-speaking group

Note: All German adjectives and nouns are declined for case, gender and number and can therefore appear in slightly modified forms. 